\title{
Economics
}

2017; 6(3): 30-37

$\mathrm{http}: / /$ www.sciencepublishinggroup.com/j/eco

doi: 10.11648/j.eco.20170603.11

ISSN: 2376-659X (Print); ISSN: 2376-6603 (Online)

\section{The Importance of International Accounting Differences in the Theory and Practice}

\author{
Lidija Romic \\ Faculty of Economic Sciences Subotica, Department of Accounting and Finance, University of Novi Sad, Novi Sad, Serbia
}

Email address:

lidijaromic7@gmail.com

To cite this article:

Lidija Romic. The Importance of International Accounting Differences in the Theory and Practice. Economics.

Vol. 6, No. 3, 2017, pp. 30-37. doi: 10.11648/j.eco.20170603.11

Received: January 19, 2017; Accepted: February 10, 2017; Published: June 23, 2017

\begin{abstract}
In this paper we will focus on why accounting and financial reporting systems developed differently in different countries. At the end we will pay attention to research approaches which try to explain, with the help of this national characteristics, the differences in the degree of accounting quality observed between various countries, even after these countries switched to mandatory compliance with IFRS for listed groups The limits mentioned are set by standard setters in different countries or international standard setters such as the IASB, which promulgate the methods of recognition and measurement, consolidation presentation and disclosure that the company must comply with. Some standard setters allow many options with regard to those issues. Other standard setters are strict and prescribe, for example one specific measurement method for a specific asset. Companies located in countries where standard setters allow many choices with regard to recognition and measurement issues have much more accounting flexibility in the presentation and valuation of this assets, liabilities, earnings and financial position. As a result, users of financial statements of companies located in countries with accounting flexibility will face more problems comparing the performance of different companies with one another than users of annual accounts of companies located in countries with very little accounting flexibility. Harmonization increases the comparability of financial information and creates more transparency for the users of financial information. As a result, the information asymmetry between stakeholders and the companies decreases. This will lead to a lower cost of capital for companies [see for example Leuz and Verrecchia, 2000, Botosan and Plumblee, 2002] and the increase in the market liquidity [Lambert et al. 2007, Daske et al. 2008]. Today the comparability of financial information published by listed groups might have improved, but the situation for the large majority of non listed companies [often SMEs] has not improved yet.
\end{abstract}

Keywords: Financial Statements, Accounting Standards, Capital Market, Culture

\section{Introduction}

All over the word stakeholders use the information provides by financial statements in their decision-making process for the purposes enumerated earlier. Although the use of the information is more ore less the same world wide, the communication of that information can differ according to the types of accounting standards used or other influencing factors [legal system, development of the capital market, enforcement of accounting standards, governance regulation, culture]. ${ }^{1}$

Information from the annual accounts becomes useful for decision making if it can be compared to a certain

1 1.Alexander, D. and Nobes C. [2004] Financial accounting; An International Introduction 2 end, Harlow, Pearson Education benchmark. Very often data taken from the financial statements of other companies are used a benchmark. However, the performance and the financial position of another company is only a yardstick for evaluation if comparability is not jeopardized by accounting flexibility, which is to large extent determined by the type of accounting standards, the risk of litigation, culture, the reporting incentives of management. Comparing two financial reports that are based on different accounting policies is like comparing two lengths without knowing that one in centimeters and other in inches.

So if the readers want to compare financial reports which are the reflection of transactions and events as recorded 
under a particular accounting policy, it is important that the accounting policies do not differ to such an extent that the comparison of financial reports is meaningless. The accounting policies or accounting decisions of a company were, and still are to a large extent, influenced by the national environment. Evidence from the first empirical studies analyzing the impact on accounting quality of the mandatory switch to IFRS for listed groups reveals that the benefits differ between countries. Differences in institutional characteristics are responsible for these results [Daske et.al 2008, Barth et al. 2008, and Armstrong et.al 2010] In a period where international harmonization or even standardization seems to be almost realized, national differences still play a role. Therefore we focus in this paper on the differences between national accounting practices and standards and national accounting environments.

Financial reporting in general can be viewed as a part of communication process. The report is a medium through which information is transferred by a sender to a receiver.

The nature and function of reporting with respect to organizations differ depending on the nature of the sender and the receiver as well as on the nature of the information transferred. The sender and the receiver form an integral part of their environment, which at the time that financial reporting developed in the past centuries was merely a national environment.

Financial reporting was, to start with, mainly internal reporting. Early financial reports can hardly be called external; they were the means by which the owners could get an insight into their income and capital. The company was a part of and managed by its owners. One could hardly distinguish between internal and external financial reports. From the early 1800 s on, the increasing scale of companies resulted in finance problems and the need for a disconnection of management and capital supply. Private capital alone was insufficient to finance business activities, so capital was gathered from people outside the company.

This separation of ownership and management makes it possible to have the company managed by people specializing in management. The owners delegate control and the evaluation of the management to the board of directors [Fama and Jensen 1983]. The board of directors also has the power to hire and fire top management and to approve any strategic decision. The directors, by way of contrast are accountable to the owners for this deeds, decisions and policy. The external financial report provides a means of rendering account of this authority. Besides the functions of profit and capital determination already mentioned, the financial report now also serves a stewardship role. An example of early external financial reporting is the accounts published by the East India Company in the eighteen century.

Financial reporting evolved from internal to external reporting, but for a long time external reporting meant providing information within the boarders of a specific country. Because national environments have different characteristics, standard setters and accounting bodies have chosen different alternatives for recognition, measurement and presentation of assets, liabilities, equity, revenue and expenses. They have chosen that recognition, measurement, consolidation, presentation and disclosure policies that best fitted their national environments. In each country annual accounts provide information on the financial position of a company and its result. Although the general mission is similar in most countries, many differences between countries occur. In each country there was, and still is, a different mix of influences on financial reporting. These differences result from different environmental, institutional and cultural influences in the individual countries. We now focus on the most important environmental, institutional and cultural differences that shaped financial reporting in the individual countries: provision of finance, the existing legal system, the link between accounting and taxation, and cultural differences between societies. These elements still influence accounting practices, even after mandatory compliance with IFRS is installed in many jurisdictions. ${ }^{2}$

\section{Provision of Finance}

According to Nobes and Parker [2003, p21] "This difference is providers of finance [creditors/insiders] versus [equity/ outsiders] is the key cause of international differences un financial reporting." We say earlier that through the increasing sale of companies two centuries ago, firms had to find extra capital to finance their growth. Companies in different countries responded differently to the increased need for funds. In countries such as Germany, France, Italy and Belgium, banks became the major supplier of extra funds. Companies in these countries relied more on debt to finance their activities than on equity. In contrast, in the UK and the USA the extra funds tend to be provided by shareholders, often by many shareholders for small amounts. Companies in these countries rely more on equity for the financing of their activities. In these countries an active stock exchange was and still is present.

Table 1. Present some examples of countries in which companies are more shareholder-oriented and countries in which companies are more credit/family/ state oriented. This divide represents the situation in the twentieth century. To a large extent, it is still representative for today's situation, especially for non listed groups and SMEs.

Table 1. Shareholder-oriented versus credit-oriented countries.

\begin{tabular}{ll}
\hline Shareholder-oriented & Credit/family/state-oriented \\
\hline United States & Germany \\
United Kingdom & France \\
The Netherlands & Belgium \\
Sweden & Italy \\
Australia & Spain \\
Canada & Portugal \\
\hline
\end{tabular}

Source: Adapted from Alexander and Nobes [2004], Nobes and Parker [2003] and Ordelheide and KPMG [2001]

22 Armstrong C, Barth M, Jagolinzer A, and Riedl E [2010] Market reaction to the adoption of IFRS in Europe, Accounting Review 
So in countries where companies are largely financed through equity, financial statements will have an investor or shareholder orientation. This means that financial statements must provide the kind of information that will enable a potential shareholder to make the best investment decision. Financial information which communicates the underlying performance of the firm in a timely manner enables investors to make those investment decisions and is called high quality accounting information. Empirical research on the quality of accounting earnings has indicated that in those countries with a strong capital market influence, the quality of accounting earnings is higher than in countries with a creditor orientation. In countries where companies rely more on debt financing, the financial statements have a creditor orientation. In these countries information provided through the annual accounts must be useful to judge whether a company is able to repay its debt. Creditor protection becomes important in this respect and accounting practices will become more conservative. These differences in financing are worth bearing in mind when companies from different countries are compared with each other for financial analysis purposes.

\section{Existing Legal System}

Over the years in Western world two types of legal system have developed: the so called common law system and the code law system. Both legal systems were exported in the $20^{\text {th }}$ century to different parts of the world. The common law system originated in England and is developed from case law. The legal system in most Commonwealth countries is the common law system. Common law is characterized as a legal system that is developed case by case and does not prescribe general rules that could be applied to several cases. In a common law situation accounting rules are not a part of the law. In common law countries accounting regulation is in the hands of professional organization of the private sector. Company law in these countries is kept to a minimum. Detailed accounting regulations are produced by the private standard setter.

The code law system originated in Roman law and has developed in continental Europe. It is characterized by a wide set of rules that try to give guidance in all situations. In code law countries the company law is very detailed and accounting standards are often embodied in the company law. Accounting regulation in code law countries is in the hands of the government and financial reporting is in those circumstances of ten reduced to complying with a set of very detailed legal rules.

Table 2 gives some examples of code law and common law countries \{See also La Porta et al, 1997, 1998]

Table 2. Common law versus code law countries.

\begin{tabular}{ll}
\hline Common law countries & Code law countries \\
\hline England and Wales & Scotland \\
United states & France \\
Australia & Germany \\
\hline
\end{tabular}

\begin{tabular}{ll}
\hline Common law countries & Code law countries \\
\hline Canada & Belgium \\
Ireland & The Netherlands \\
New Zeland & Portugal \\
Singapore & Spain \\
& Japan \\
\hline
\end{tabular}

Source: Adapted from Alexander and Nobles [2004] Nobles and Parker [2003] and Orderlheide and KPMG [2001]

Related to the legal system is the degree of enforcement of the legal rules or standards by the judicial authorities or a supervising body. Very often in common law countries the degree of enforcement and the mechanism for investor protection are much stricter than in code law countries. However, this distinction is disappearing slowly. Recently code law countries are changing their regulations in order to guarantee a stricter enforcement of the application of accounting standards. ${ }^{3}$

\section{Link Between Accounting and Taxation}

In some countries the fiscal authorities use information provided in the financial statements in order to determine taxable income. In a number of continental European countries expenses are tax deductible only if they are also recognized in the profit and loss account. As a result financial reporting becomes tax influenced or even tax biased. In this respect, Germany is well known for its Massgeblichkeitsprinzip, which stands for the fact that the tax accounts \{Steurbilanz] should be identical to the accounts published for external stakeholders \{Handelsbilanz]. This link between financial reporting and taxation is often found in those countries that do not have an explicit investor approach in their financial reporting orientation.

In countries like the USA, the UK and the Netherlands the link between taxable income and accounting income is much weaker. Separate accounts are filed for tax purposes. The measurement and recognition rules and estimates used in the accounts can differ from the valuation rules used in the preparation of the financial statements published for all external stakeholders. Table 3 shows the general relationship between accounting and taxation using some examples based on the situation in the $1990 \mathrm{~s}^{4}$

This relationship between accounting income and tax income can vary over time. For example, Spain was for a long time in the column of dependence, with the reform of 1989, however, the link between taxable income and accounting income became less strong and they are now moving towards independence. The introduction of

\footnotetext{
3. Maijor, S and Vanstraclen, A [2006] Earnings management within Europe; the effects of member state audit environment, audit firm quality and international capital markets, Accounting and Business Research 36

4. Bughstahler, D.C Hail, L. and Leuz C. [2006] The importance of reporting incentives; earnings management in European private and public firms, Accounting Review 81
} 
International Accounting Standards will have an impact on the relation between accounting and taxation in those countries characterized by a dependence relationship, especially when SMEs will start to use IFRS for private entities in the near future.

Table 3. General relationship between accounting and taxation.

\begin{tabular}{ll}
\hline Independence & Dependence \\
\hline Denmark & Germany \\
Ireland & France \\
United Kingdom & Belgium \\
The Netherlands & Italy \\
Czech Republic & Sweden \\
Poland & Norway \\
\hline
\end{tabular}

Source: Adapted from Alexander and Nobles [2004], Nobles and Parker [2003] and Ordelheide and KPMG [2001]

\section{Cultural Differences}

Research indicates that another cause of variation between national accounting systems is cultural differences. Cultural differences between nations are identified as an important influencing factor on reporting and disclosure behavior with regard to financial statements. One of the prominent researches on cultural differences is Hofstede [1984]. He used four constructs to classify countries according to the cultural differences he observed in his empirical research. The constructs resulted from empirical survey-based research in one multinational [IBM, survey population 100000 employees in 39 countries, 1984] Hofstede labeled his constructs as follows, individualism, power distance, uncertainty avoidance and masculinity. According to Hofstede, these labels describe the following characteristics of a society.

\subsection{Individualism Versus Collectivism}

Individualism stands for the preference for a loosely knit social framework in society wherein individuals are supposed to take care of themselves and their immediate families only. Collectivism describes the preference for a tightly knit social framework in which individuals expect their relatives, clan or other in - group to look after them in exchange for unquestioning loyalty. The fundamental issue addressed by this dimension is the degree of interdependence a society maintains among individuals. This difference relates to the peoples self concept: I or we.

\subsection{Large Versus Small Power Distance}

Power distance is the extent to which the members of a society accept that power in institutions and organizations is distributed unequally. People in larger power distance societies accept a hierarchical order in which everybody has a place that needs no further justification. The fundamental issue addressed by this dimension is how society handles inequalities among people when they occur. ${ }^{5}$

5. Daske, H, HailL, Leuz C and Verdi R. [2008] Mandatory IFRS reporting around the world; early evidence on the economic consequences, Journal of

\subsection{Strong Versus Weak Uncertainty Avoidance}

Uncertainty avoidance is the degree to which the members of a society feel uncomfortable with uncertainty and ambiguity. This feeling leads them to beliefs promising certainty and to maintain institutions protecting conformity. Strong uncertainty avoidance societies maintain rigid codes of belief and behavior and are intolerant of deviant people and ideas. Weak uncertainty avoidance societies maintain a more relaxed atmosphere in which practice counts more than principles and deviance is more easily tolerated.

\subsection{Masculinity Versus Feminity}

Masculinity stands for the preference in society for achievement, heroism, and assertiveness and material success. Its opposite, feminity, stands for the preference for relationships, modesty, caring for the weak and the quality of life.

Based on Hofstedes classification scheme, Gray [1988] defined accounting values that can be linked to the different cultural values as follows:

- Professionalism versus statutory control

- Uniformity versus flexibility

- Conservatism versus optimism

- Secrecy versus transparency.

\subsection{Professionalism Versus Statutory Control}

The accounting value professionalism links to individualism. Professionalism is consistent with a society where the emphasis is on me rather than us. Professionalism also goes together with a society with small power distance. Statutory control is observed in the opposite situation, namely in societies with large power distance. In relation to the accounting profession, professionalism implies self regulation by the accounting profession itself, as in the USA and the UK and much less in continental Europe. Statutory control implies control by the government. Statutory control could also be linked to strong uncertainty avoidance.

\subsection{Uniformity Versus Flexibility}

First of all, uniformity can be linked to strong uncertainty avoidance. Uniformity leads to detailed regulations embedded in the law and adherence to consistency [e.g. in Belgium, France and Spain uniform accounting plans were imposed on companies by law] Uniformity is therefore also associated with large power distance societies and societies in which the emphasis is on we rather than I. Flexibility, however, can be associated with weak uncertainty avoidance, small power distance and individualism. ${ }^{6}$

\subsection{Conservatism Versus Optimism}

Conservatism could be linked to uncertainty avoidance. In

Accounting Research 46

6. Ordelheide, D and KPMG [2001] Transnational Accounting 7 
these societies one is more conservative with regard to profit recognition and asset measurement. Conservatism is an important value for accountants, especially in continental Europe where financial reporting is more creditor-oriented and where there is a strong link between accounting income and taxable income. Less conservatism in the accounts is applied in the UK, the USA and the Netherlands in comparison to France, Switzerland and Germany.

\subsection{Secrecy Versus Transparency}

Secrecy implies a preference for confidentiality. Secrecy can be linked to uncertainty avoidance, but also to societies with large power distances. Information asymmetry will then reinforce inequalities and power relations between the different parties. Secrecy will have a direct impact on the level of information disclosure by companies. In Japan and continental Europe lower levels of information disclosure are observed in comparison to disclosure levels in the USA and the UK.

The most important economic and cultural elements cited in the literature as causes for differences between national accounting systems have now been discussed. Other factors also listed in the literature as contributors to those differences are, for example, the level of economic development in a country, the degree of industrialization, inflation levels, the adherence to accounting theory [e.g. in the Netherlands income determination and valuation is inspired by the theory of Limperg [May 1966] financial reporting in Germany was inspired by the theory of Schmalenbach [1927].

In the next part of the paper we will analyze how these different economic and cultural factors shaped financial reporting practices and standards in each individual country. The causes for differentiation had an influence on the existing accounting system and on the implementation of IFRS in a country.

\section{Differences in Accounting Systems}

Since accounting responds to its environment, different cultural, economic, legal and political environments produce different accounting systems, while similar environments produce similar accounting systems.

In this section we focus on the differences in accounting systems. In the next section the emphasis lies on the different sets of domestic generally accepted accounting principles [GAAP], which still exist for large numbers of non-listed entities worldwide. Under the heading of accounting systems we discuss two elements that characterize accounting systems, namely the organization of accounting regulation and the organization of the accounting profession.

\subsection{Types of Accounting Regulation}

We can distinguish between two types of accounting

7 Schipper, K [2000] Accounting research and the potential use of international accounting standards for cross border securities listings, British Accounting Review 32 regulation, namely private sector accounting standard setting or public sector accounting standard setting. When shareholders are the main providers of capital we expect them to have great interest in the way in which companies communicate their financial information. The shareholders will definitely want to have a hand in the communication process, including the financial reporting process. The shareholders are mainly trying to achieve this objective by hiring professional accountants who check on their behalf the communication process and its outcome within a company. In order to be able to fulfill their task properly, preparers together with the accountants started to play a major role in the standard setting process of those countries characterized by active capital markets.

We observe that in countries with a code law system and a creditor orientation, the government sets the accounting standards and often makes use of financial reporting for their own purposes. Firs of all, in those countries the annual accounts are often used for tax purposes which serves the government. Second, the financial statements may be used for specific information needs of the government. [In Belgium, for example, the social balance sheet - a document containing employment statistics, e.g. number of employees, breakdown into different categories, change in the workforce, use of government incentives for the creation of employment - must be included in the financial statements by Royal Decree of 1996. It mainly serves the need of the government for information with regard to employment in order to evaluate the effectiveness of their governmental employment policies] Financial reporting in those countries essentially comes down to compliance with legal requirements and tax laws.

So there are two types of accounting regulation, each of which is embedded in a different economic and legal environment. First of all, there are countries in which accounting regulation is in the hands of the private sector: the UK, the USA, Australia and the Netherlands. In these countries private standard setting goes together with a shareholder orientation of the financial information published and, in most countries, a common law system. Second, there are countries in which the government plays a major part in accounting regulation. This system is observed in many continental European countries. In those countries detailed accounting rules are embodied in the law, normally the company law. Financial information has mainly a creditor orientation in those countries and they are further characterized by a code law system. These two types of accounting regulation still apply for the time being to non listed groups and small and medium size entities. With the compulsory introduction of the International Financial Reporting Standards, a substantial number of countries with diverse backgrounds now operate in a similar setting with regard to accounting regulation. This implies that UK and USA constituents are much more familiar with a due process of private standard setting than European continental preparers who originate from a public sector standard setting environment. 


\subsection{Differences in the Organization of the Accounting Profession}

When companies are financed by equity capital and if this equity capital is in the hands of a widespread group of small shareholders, these shareholders are in need of a well organized control system with regard to the quality and reliability of the information provided by the financial statements. The strength and size of the accounting profession is directly influenced by the need for the external control mechanism or audit of the published financial information. In countries with a well organized accounting profession we observe that the influence of that profession on local accounting practices an on national GAAP is larger than in countries with smaller and later developed professional organization.

\section{Characteristics and Differences in National GAAP}

All these institutional and economic differences lead to differences in accounting systems [e.g. regulation] these accounting systems produce different national or domestic accounting standards. The following points illustrate several differences in financial reporting characteristics. Although they are presented as separate items, they are linked together.

\subsection{Shareholder Orientation Versus Stakeholder Orientation}

In countries with widespread ownership there is a need for high-quality published financial information. Ac companies have to rely to a large extent on the capital market, information disclosure becomes extremely important because existing and potential shareholders do not have access to internal information in order to assess the financial situation of the company they might want to invest in or increase their investment in. In those countries the pressure for disclosure is much greater than in countries where providers of finance have the power to obtain internal information. Besides the need for more disclosure and more auditing, the debt versus equity orientation also has a direct influence on valuation issues.

In equity- oriented countries financial reporting is aimed at communicating the performance and efficiency of the business to existing and potential shareholders. Profit measurement is very important and reported data on earnings, financial position and cash flow will be used to make predictions about the future recurring stream of earnings, cash flow and the financial position of the company. In countries where companies are financed trough debt, financial statements serve the information needs of many different stakeholders, especially creditors, and also the government. Their information needs are concerned with the value of underlying assets of the company as collateral and the determination of taxable income. The debt/equity orientation lies at the origin of the different reporting and principles described next.

\subsection{Fairness Versus Legality}

In common law countries the aim of financial reporting is a fair representation of the financial situation of the company. In the UK this is translated into the true and fair view concept. In code law countries financial reporting is focused on compliance with the legal requirements and tax laws. This often leads in code law countries that the legal form to dominate the substance. The most cited example in this respect in the accounting treatment of a lease contract. In countries with strong shareholder orientation and emphasis on fairness, lease contracts are accounted for on the balance sheet although the company is not the legal owner of the assets [e.g. the UK and the USA]. In countries where the legal form prevails, these assets used by company are often kept off balance sheet as the company is not he legal owner [e.g. until recently, France]. ${ }^{8}$

\subsection{Conservatism Versus Accruals}

In countries in which financial reporting is more creditor-oriented and used for tax purposes, valuation rules will be more conservative or prudent than in countries with a shareholder orientation. Adherence to conservatism versus accruals will lead to a different choice in valuation rules and accounting practices. For example, with regard to depreciation, the declining balance method will be used more often than the straight line method, if conservatism is an important characteristic in financial reporting. Further, more use will be made of provisions in these countries, especially when provisions are tax deductible. Conservative accounting if often regarded as a system in which lower profits are reported than under a system driven by accrual accounting. However, with the use of extensive depreciation and creation of provisions, those companies are also able to increase results in periods with weak economic performance.

Much research is undertaken with regard to the quality of earnings reported under conservative accounting. With quality of accounting information, one refers to the use of accounting data for the prediction of future performance [value relevance of accounting information]. The results of these studies reveal that information provided under conservative accounting practices is less value relevant [e.g. see Basu, 1997, Pope and Walker, 1999, Penman and Zhang 2002]

\subsection{Uniformity Accounting Plans and Formats}

In code law countries we observe that the regulator attaches importance to uniformity. Compliance with prescribed accounting plans [France, Spain and Belgium] and

8 4.Daske, H, HailL, Leuz C and Verdi R. [2008] Mandatory IFRS reporting around the world; early evidence on the economic consequences, Journal of Accounting Research 46 
detailed formats for the balance sheet and the profit and loss account are a result of this drive for uniformity. When regulation is in the hands of the government, the layout of the balance sheet, profit and loss accounts and notes are much more detailed. The schemes for balance sheet and profit and loss account put forward by the Fourth and Seventh Directives of the EU are more detailed than the layout presented by the IASB. On the other hand, the level of detail in the notes to the balance sheet and profit and loss account is much higher when accounts in compliance with IFRS are prepared.

\subsection{Consolidated Accounts}

In countries where financial reporting has a strong shareholder orientation, the practice of preparing and publishing consolidated financial statements emerged much earlier. Preparing consolidated financial statements was already common practice at the beginning of the twentieth century in the USA [in the 1920s] In the UK and the Netherlands consolidation became common practice in the 1930s. In typical creditor orientation countries, which are usually also code law countries, twentieth century [Germany 1965 Aktiengesetz for public companies, France 1985, a law which obliged listed companies to publish consolidated accounts, Belgium, the Royal Decree of March 1990, in Italy consolidation became compulsory in the early 1990s]

\subsection{Deferred Taxation}

In countries with no direct link between tax income and accounting income the practice of recording differed taxes on the balance sheet is well established and common practice. For countries in which there is a strong link between accounting income and tax income, the practice of recording and calculating deferred taxes is relatively new. Further in the individual accounts of companies in those countries the amounts recorded under deferred taxes will be rather small. ${ }^{9}$

\section{National Differences: Do They Still Play a Role in an ERA of Globalized Accounting}

Even when all companies comply with US GAAP or IAS/IFRS, academic research provides evidence that national influences still affect the quality of financial reporting in the different countries. Empirical research provides us with evidence of this influence, and this is another reason why we have paid so much attention to such national variables in this paper.

The variables pointed out by researches in the 1970s and 1980s as causes that might explain and have led to differences in national accounting systems and national GAAP are now used in empirical multi-country studied in which different aspects of the financial reporting practices of companies are

9 Schamalenbach E [1927] Der Kontenrahmen, Zeitshrift fur btriebswirtschafliche Forshung 21 researched. These studies focus, on among other things, the value relevance of accounting information, earnings, management practices and characteristics of the audit market and audit process. A few examples of these empirical studies will be presented hare together with their research results. In the first decade of the twenty-first century, most empirical studied analyzed either the quality of the accounting information of firms that adopted IFRS or US GAAP on a voluntary basis, or the quality of accounting information from companies subject to similar types of accounting standards, but different institutional regimes [e.g. risk of litigation, degree of enforcement, degree of investor protection]

Ali and Hwang [2000] found that the value relevance of accounting information in lower for countries with bankoriented [as opposed to market oriented] financial systems. Value relevance was specified in terms of explanatory power of accounting variables [earnings and book value of equity] for security returns. Their results indicate further that value relevance of accounting income is lower for countries where private sector bodies are not involved in the standard-setting process. Ball et al. [2000] investigated two properties of accounting income [conservatism and timeliness] and the influence of international institutional factors on accounting income. The property timeliness is defined as the extent to which current period accounting income incorporates current period economic income. Conservatism has been used in this study using rent period income asymmetrically incorporates economic losses relative to economic gains. Their central result that accounting income in common law countries is significantly timelier than in code lay countries, due entirely to quicker incorporation of economic losses which means more income conservatism. ${ }^{10}$

Guenther and Young [2000] investigated how cross country differences in legal systems, differences in legal protection for external shareholders, and differences in the degree of tax conformity affect the relation between financial accounting earnings and real economic value-relevant events that underlie those earnings. These results provide evidence that the association between financial accounting earnings and real economic activity in a country is related in predictable ways to the legal and economic systems that underlie financial accounting standard setting and the demand for financial accounting standards. The high association for the UK and the USA and low association for France and Germany are consistent with expectations that accounting earnings in common law countries, countries with legal systems that protect external shareholder rights, countries with legal systems that protect external shareholder rights, countries with market oriented [rather than bank oriented] capital markets, and countries where financial accounting rules are independent of tax rules better reflect underlying economic activity. Not only do the traditional elements of differentiation [provision of capital, legal system, and link with taxation] seem to be relevant, but also elements such as risk of litigation, investor

10 Seidler Lj,[1967] International accounting the ultimate theory course, Accounting review 42 
protection and enforcement of accounting rules are important factors that explain differences in reporting behavior.

Leuz et al. [2003] found that the quality of financial reports increased in countries where investor protection is stronger. Their findings suggest an important link between legal institutions and the quality of financial information provided. The legal rights accorded to outside investors, especially minority investors, and the quality of their enforcement is both associated with the properties of firms accounting earnings. Their study indicated further that a switch to high-quality standards alone was not a guarantee for high- quality financial information. Other academics had also put forward this issue. For example, Schipper [2000] stated that:" Reporting quality is not only a function of the set of standards applied. High quality standards implemented in a defective manner will not result in high quality financial reports" Without adequate enforcement, even the best accounting standards will be inconsequential. Hope [2003 a, 2003b] constructed an enforcement index which took into account judicial efficiency, rule of law, anti director rights, audit firm type, audit spending, stock exchange listings and insider trading. Hope found evidence that the enforcement score varied widely among countries. Therefore, accounting quality will still differ among countries even if they apply the same set of accounting standards.

Maijor and Vanstraelen [2006] in their study put forward the idea that the international comparability of earnings reported depends not only on the set of accepted accounting standards, but also on the national quality of audits and the constraints imposed on earnings management by the national audit environment. In their research they studied earnings management in France, Germany, the Netherlands and the UK. Although companies in all four countries engage in earnings management, its magnitude is not uniform across the four. Prior research focused almost exclusively in differences in earnings quality among the national jurisdictions with regard to listed companies. Recent research paying attention to non listed companies confirms to a large extent the results found in relation to listed companies [Burghsahler et al., 2006].

The research results in the articles cited above are based on financial information published by companies that complied on a voluntary basis with IFRS. A stream of research is now under way to find out whether accounting quality differs among countries in which listed groups have to comply on a mandatory basis with IFRS. The first articles researching accounting quality among companies which now comply with IFRS on a mandatory basis still point at differences in accounting quality among IFRS accounts driven by national institutional differences [Daske et al. 2008, Barth et al. 2008, Armstrong et al. 2010]. Daske et al. [2008] find that the positive capital market benefits of IFRS only occur in countries where firms have incentives to be transparent and where legal enforcement is strong, underscoring the central importance of firms reporting incentives and countries enforcement regimes for quality of financial reporting. The impact of IFRS is sometimes difficult to single out, since a number of countries have also changed their corporate governance regulation and enforcement practices at the same time. Further, we have to be aware that companies applying IFRS for the first time since 2005 are going through a learning curve. This learning curve might have an impact on the quality of the information published.

\section{Summary}

In this paper we outlined the major influencing factors which led to differences in the development of national accounting environments and national reporting practices from the eighteenth century until the end of the twentieth century and beyond. Empirical research conducted in the 1970 s and the 1980s indicated the following variables as important determinants of those differences; provision of finance, the legal system, the link between accounting and taxation and cultural values.

From the 1970s on a movement towards harmonization of financial reporting started slowly to emerge. From the 1990s on under pressure from multinational companies seeking dual listings to attract capital, the request for one set of GAAP to be applied worldwide emerged. Meanwhile, as attempts for worldwide harmonization and standardization are undertaken, national institutional differences still influence, to some extent the output of the financial reporting process of listed companies and even more so of unlisted companies.

\section{References}

[1] Alexander, D. and Nobes C. [2004] financial accounting; An International Introduction 2 edn, Harlow, Pearson Education.

[2] Armstrong C, Barth M, Jagolinzer A, and Riedl E [2010] Market reaction to the adoption of IFRS in Europe, Accounting Review.

[3] Bughstahler, D. C Hail, L. and Leuz C. [2006] the importance of reporting incentives; earnings management in European private and public firms, Accounting Review 81.

[4] Daske, H, HailL, Leuz C and Verdi R. [2008] Mandatory IFRS reporting around the world; early evidence on the economic consequences, Journal of Accounting Research 46.

[5] Lambrt, R, Leuz, C and Verrecchia R [2007] Accounting information, disclosure and the cost of capital. Journal of Accounting Research 45.

[6] Maijor, S and Vanstraclen, A [2006] Earnings management within Europe; the effects of member state audit environment, audit firm quality and international capital markets, Accounting and Business Research 36.

[7] Ordelheide, D and KPMG [2001] Transnational Accounting 7.

[8] Schipper, K [2000] Accounting research and the potential use of international accounting standards for cross border securities listings, British Accounting Review 32.

[9] Schamalenbach E [1927] Der Kontenrahmen, Zeitshrift fur btriebswirtschafliche Forshung 21.

[10] Seidler Lj, [1967] International accounting the ultimate theory course, Accounting review 42. 